\title{
Implementation of student's worksheet based on project based learning (pjbl) to foster student's creativity
}

\author{
Sahtoni $^{1}$, Agus Suyatna2, and Posman Manurung ${ }^{3}$ \\ Lampung University ${ }^{123}$ \\ E-mail: sahtoni@gmail.com
}

\begin{abstract}
This study aimed to foster student creativity through the use of student worksheet based on Project Base Learning (PjBL) on dynamic electrical material in making alternative power sources. The research method is using a pre-experimental design with One-Shot case study type. The study population was students of class IX MTs Al-Islah in Pesawaran Lampung. A sample of one class consisting of 30 people was obtained by purposive sumpling. Data analysis was done by using descriptive concerning creativity, product, and response of students to see effectiveness of learning. The results showed that the application of student worksheet based on project based learning is overall effective to foster creativity of student. Based on the average of student's creativity, the result is $80 \%$ which categorized as "creative." Based on the average of student's product, the result is $76.2 \%$ which categorized as "valuable." The student's response is positive as much as $92 \%$ which categorized as "very agree."
\end{abstract}

Keyword : worksheet, project based learning, creativity

\section{Introduction}

Implementation of education in schools is a means to train students to meet standards, to master knowledge, foster creativity and have the ability to solve problems. However, according to [1] most education in schools still does not support the growth and development of student's creativity. Student tends to be required to provide the correct answer according to the teacher and given less opportunity to provide alternative answers that foster creativity.

Based on the results of the interviews of science teachers in both public and private schools, it is found that, (1) the learning outcomes of science are still in the low category, especially in dynamic electrical materials; (2) there is still the limitation of teaching materials / learning media in explaining dynamic electrical materials; (3) the method used is also only with the lecture method, the learning is still centered on the teacher, which causes the students to be passive; (4) the daily test result in semester 1 of academic year of 2015/2016 shows that students do not pass the passing grade. This is because the students experienced more misconception on dynamic electrical material. This result is supported by [2] research that shows about 32 out of 40 students on average experience a misconception of dynamic electrical matter, such as on voltage 
sources, current strength, voltage, electrical resistance in series and parallel circuits. So, the students feel confused by the material, and difficult to understand the concepts in dynamic electricity and in growing their creative thinking skills.

One of the efforts to overcome this problem is by the implementation of Student Worksheet model of Project Based Learning (PjBL). A research by [3] states that the learning tools $\mathrm{PjBL}$ model that is produced effectively can be used to enhance the creativity of students, especially on aspects of creative thinking ability.

The project-based learning model can bridge students to develop student's creativity through project-based problem-solving activities. It is as stated by [4] that the projectbased learning model is one of the excellent learning models in developing the basic skills students must possess, such as decision-making skills, creativity skills, and problem-solving skills. This statement is similar to the results of [5] research that project-based learning methods can encourage students to think creatively and solve problems. Furthermore, [6] research states that outdoor education on the project-based can improve students' creative thinking skills in creating projects.

Student worksheet PjBL model that has been developed by researchers leads students to solve problems by making products in the form of tools that can create alternative power source about dynamic electrical materials, in the hope that students can understand the concept of dynamic electricity and grow their creativity. This statement is in line with [7] research that project-based learning involves students in problemrelated activities and at the peak to produce valuable, realistic student's work products. The outcomes produced by the students will then be assessed to see the skills or creativity of the students in making the product and the quality of the product [8]. Product ratings can also make students develop their creativity, potential, and skills. This assertion is supported by a study by [9] which states that product assessment can improve student competence comprehensively.

Based on the above background, this study aims to implement student worksheet PjBL model in fostering student creativity.

\section{Method}

\subsection{Research Design}

The design applied in this study is a pre-experimental design with One-Shot case study type [10].

\subsection{Participants}

This research recruited students at MTs Al-Islah in Pesawaran of Lampung. The study population was IX MTs Al-Islah class in Pesawaran. The Samples were one class consisting of 30 people that were obtained by purposive sampling technique with some considerations. 


\subsection{Procedure}

In the design of this study, there was a group that is treated, and then the result is observed again [10]. In this experiment, researchers presented subjects with several types of treatment, and then the results are measured so that this study conducted onetime data collection. Furthermore, to know how effective it is to use in fostering the creativity of student, hence the percentage of creativity value of student and product yielded of the student, are counted and analyzed by description. Student creativity indicators measured are planning, exploring in product design, interdisciplinary, choosing the right materials, and using tools. For student, product indicators include product functionality, product durability, product benefits, product economic value, product aesthetic value, and show innovation and creation in manufacturing techniques.

\section{Results and Discussion}

Researchers apply observation data on students' creativity and product to obtain effectiveness test data. Then from the observation data, the value of the creativity index and its products, are searched by calculating the percentage score, then the score is described according to criteria of creativity and value of student products.

In the assessment creativity, student is evaluated based on an assessment rubric consisting of five indicators, starting from the project planning to the making of a simple tool product of alternative energy generation.

Table 1. Assessment of student creativity

\begin{tabular}{clcc}
\hline No & Indicator assessed & Percentage $(\%)$ & Category \\
\hline 1 & Planning and developing ideas & 88.9 & Very creative \\
2 & Exploring in product design & 66.7 & Creative \\
3 & Interdisciplinary science & 44.4 & Fairly Creative \\
4 & Choosing the right materials & 100 & Very creative \\
5 & Using the tool & 100 & Very creative \\
& Average & 80 & Creative \\
\hline
\end{tabular}

Student creativity as a whole has an average of $80 \%$ with "creative" criteria. As shown in Table 1, of the five observed indicators, the "choosing the right materials" and "using the tool" indicators have the highest score of $100 \%$ which categorized as "very creative", while the indicator "interdisciplinary science" has the lowest score.

In the product assessment, students are assessed based on some predetermined indicators. Assessment of student products is in Table 2.

Table 2. Assessment of student products

\begin{tabular}{clcc}
\hline No & Indicator assessed & Percentage (\%) & Category \\
\hline 1 & Functional products & 66.7 & Valuable \\
2 & Originality of products & 100 & Very valuable \\
3 & Product durability & 100 & Very valuable \\
\hline
\end{tabular}




\begin{tabular}{clcl}
\hline 4 & Product benefits (generating electrical energy) & 100 & Very valuable \\
5 & The economic value of the product & 66.7 & Valuable \\
6 & The aesthetic value of the product & 44.4 & Fairlyvaluable \\
7 & $\begin{array}{l}\text { Demonstrate innovation and creation in } \\
\text { manufacturing techniques } \\
\text { Average }\end{array}$ & 55.6 & Fairlyvaluable \\
& 76.2 & Valuable \\
\hline
\end{tabular}

The resulting student score has an average of $76.2 \%$ which categorized as "valuable." As shown in Table 4.5, of the seven indicators observed, the indicators of "product originality", "product durability", and "product benefit (generating electrical energy)" have the highest score of $100 \%$ which categorized as "very valuable", while the indicator of "aesthetic value of the product" has the lowest score compared to other indicators that are $44.4 \%$ which categorized as " Fairly valuable."

In the data collection of student learning responses using student worksheet, the result of the development is listed through the spreading of the questionnaire in which each statement has different responses.

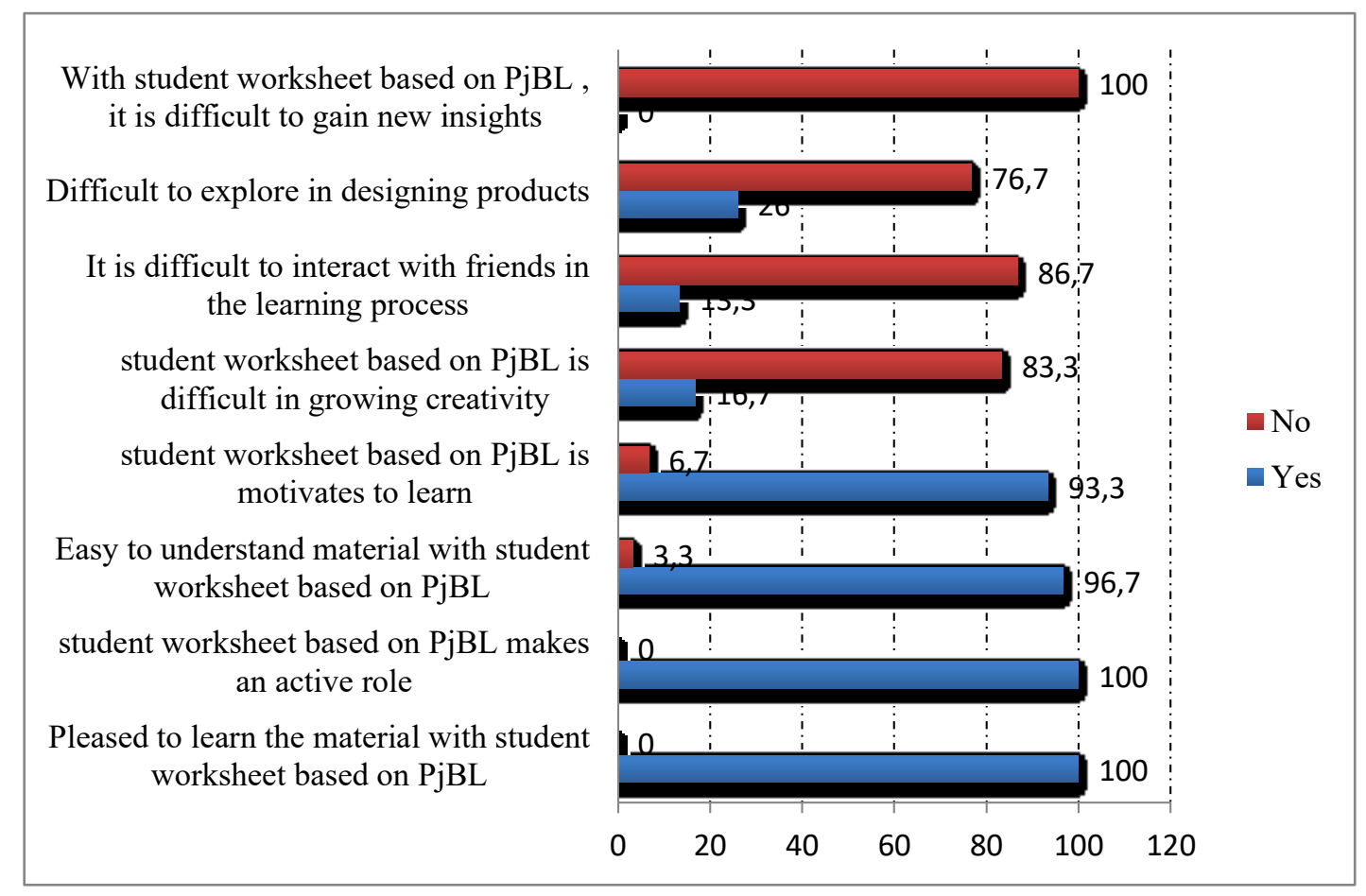

Figure 1. Data of student response

In Figure 1the result for a positive response answer of $100 \%$ of students stated "strongly agree" to student worksheet PjBL model that it can make students play an active role, and happy to learn the material with the student worksheet. Then as many as $96.7 \%$ of students "strongly agree" to the statement of easily understand the material with student worksheet model $\mathrm{PjBL}$, and $93.3 \%$ of students also "strongly agree" that student worksheet $\mathrm{PjBL}$ model is very motivating in learning. Meanwhile, for the response of negative answers as much as $100 \%$ of students stated "strongly disagree" that student worksheet model PjBL does not given new insights. As many as $76.7 \%$ of students 
strongly disagree that the student worksheet model of $\mathrm{PjBL}$ is formidableto explore in product design. Then as much as $86.7 \%$ of students strongly disagree that learning with student worksheet is difficult in interacting with friends, and as many as $83.3 \%$ of students strongly disagree that student worksheet with $\mathrm{PjBl}$ model can not grow creativity.

The results of data analysis Table 1 shows that the indicator of creativity assessment in planning and developing ideas on the activity has a score of $88.9 \%$ with the criteria of "very creative." This statement is in line with [11] opinion that creativity is a capability that can grow through the problem-solving process. The same thing is expressed by [12] that when students undertake project activities to produce products, students will also involve their creativity. Creativity is needed to generate new ideas to solve problems, make improvements, increase effectiveness, and add value.

For the indicator of creativity in choosing materials, has a high value of $100 \%$ with the criteria of "very creative." This statement is consistent with [6] research that the implementation of project-based learning can improve creative thinking skills, such as students can create detailed project designs, ranging from project titles, determining tools and materials, work methods, and everything related to the project created.

Indicators using tools and materials have a high value of $100 \%$ with the criteria of "very creative." Most groups of students can choose eco-friendly equipment according to the plan.

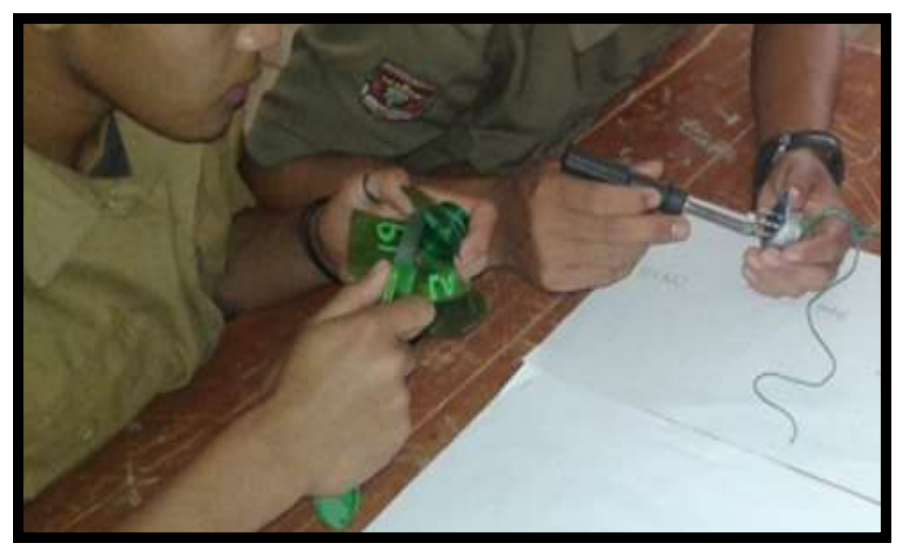

Figure 2. Use of tools and materials

In the making of the windmill in Figure 2, the student with his group makes the windmill directly with the base material of the used bottle. The bottle used is varied; the goal is to find the windmill in which bottle base material is best in rotating the DC generator to convert motion energy into electrical energy. It belongs to the creative category, as ideas emerge in making windmills. This statement is supported by a research conducted by [13] which states that effectual project-based learning applications focus on the creativity of thinking, problem-solving, and interaction between learners with peers to create and use new knowledge. Furthermore [14] research states that students will have the creative ability when faced with various skills and decision making through project learning. 
For the indicator of creativity to explore and develop ideas in designing the product has a score of $66.7 \%$ with the criteria of "creative."

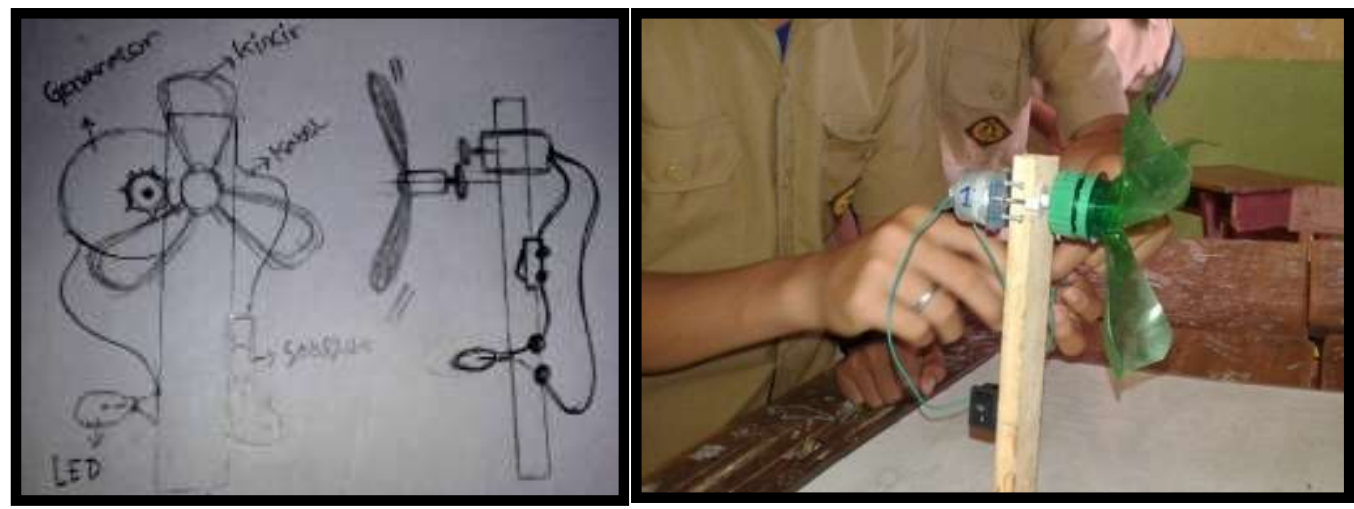

(a)

(b)

Figure 3. Exploration in product design, (a) product design, (b) final product.

By using their creativity in designing and manufacturing/assembling the products, students create and innovate by using additional materials (boards/wood) to place the holder or buffer of the mill with its generator, to make the product stout and sturdy when receiving wind gusts.

Project-based learning improves students' creative thinking skills; this is because students center to the learning process and become more active and collaborative with their group from the project process that has been done [15]. This thought is in link with [16] research that the PjBL model is a learning model that enables students to learn, and also improves the students' creativity in producing something from the project they are working.

The next indicator of creativity is interdisciplinary science; this indicator has a value of $44.4 \%$ with the criterion of "quite creative." During the process of planning, manufacture and until the creation of products, students find some problems that hinder the success of a product. However, students are quite creative in dealing with the problem. Some students use the approach in solving a problem by using a review of the various relevant cognate science points of view. What scientific point of view students use is that by considering 1-2 other aspects of science.

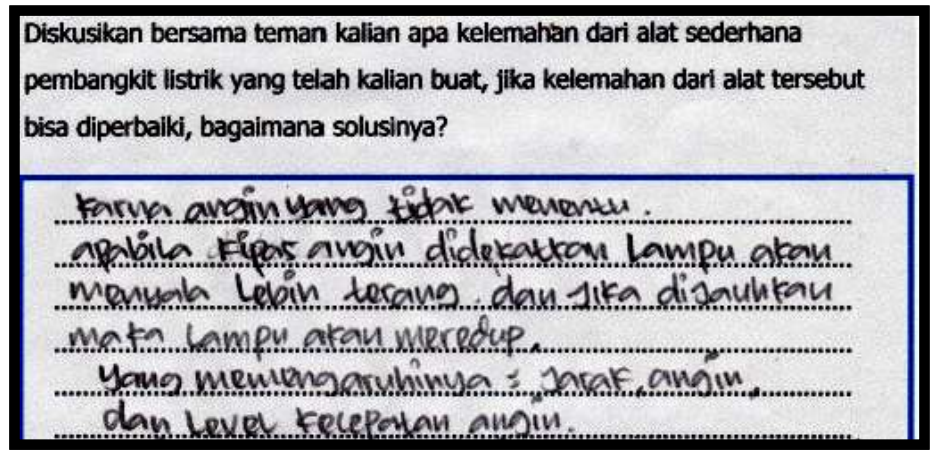

Figure 4. Examples of interdisciplinary understanding of science are quite creative 
As[17] opinion, that to develop interdisciplinary, creativity of knowledge must be elaborated through the PjBL model, since the model is a lesson designed for complex multidisciplinary problems that are oriented toward the product.

The results of the data analysis Table 2 shows that the product made by the students has functioned as an alternative power generator tool which is useful in society or in an area that has not yet been reached by PLN. The product made with a large scale can help community activities in daily life. The students outcomes have originality or something new to them. The durability of the product is quite good because researchers can use it repeatedly.

The experiments carried out on the product are successful, as they can generate electrical energy, which is marked by the LED light.

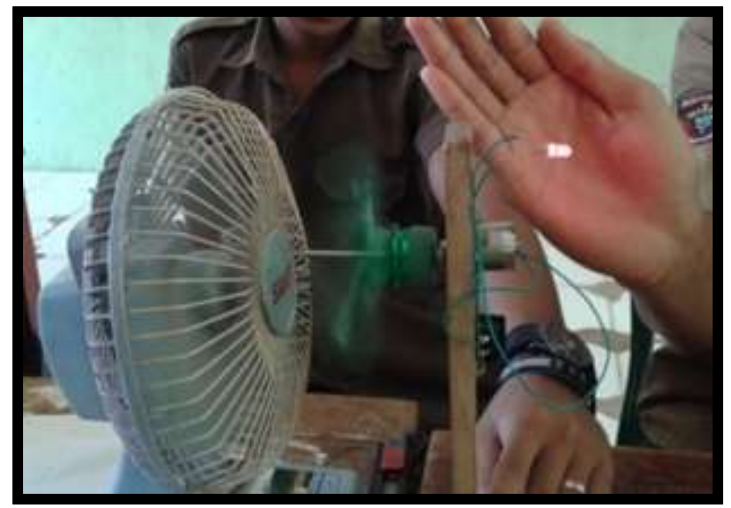

Figure 5. Product trial

For the aesthetic value, the product has a simple artistic element, but in its formation, the product has an element of innovation or creation. The students use wood or board as the supporting pole, arrange, and place the parts of the power plant in such a way to make it beefy and not easily loose towards a gust of wind.

The result of the data analysis in Figure 1 shows that the students respond to the average positive statements of $97.5 \%$ with the criteria of "strongly agree," and for the average negative disclosure of $86.7 \%$ the students stated, "strongly disagree." So it can be concluded that as many as $92 \%$ of students declared strongly agree on learning by using student worksheet model PjBL. This report is in link with [18] research indicating that as many as $76 \%$ of students respond positively to project-based learning. Similarly, [19] observed that the average student in grade VIII agreed to study the project model by $92 \%$.

Students who claimed to gain new insight responded (100\%), were happy to study the material with student's worksheet model of $\mathrm{PjBL}$ as much as $100 \%$, and $96.7 \%$ easy to understand the material with student worksheet of PjBL. [20] reveals that students will easily understand a material when he or she performs an activity to learn it, which will make them enjoy the learning process. [21] research shows that PjBL is assisting in investigations that lead to students in solving broader real problems, giving pleasure in learning, and will be an effectual and strategic lesson. 
As much as $83,3 \%$ of student response stated that learning with student worksheet of PjBL can grow student's creativity, 93,3\% stated that student is motivated to learn, $100 \%$ student can role actively, $86,7 \%$ express easy to interact with friend in learning process, and $86.7 \%$ of students stated easy to explore in designing the product. This result is in line with the opinion by [22] that "the PjBL model is a model that exposes students to relevant learning, which positively influences students' creativity development, enabling students to actively explore knowledge, ask questions, find problems, designing, and implementing projects." Furthermore, PjBL can also help to create cooperation and interaction among learners, which is similar to the way they live in their society [23].

\section{Conclusion}

Student worksheet project-based learning model is effectual in generating students' creativity in dynamic electrical materials, based on students' creativity is $80 \%$ which categorized as "creative" and the value of the students' products is $76.2 \%$ which categorized as "valuable." Students give a positive response of $92 \%$ with the category "very agree" in learning using student worksheet model PjBL.

\section{References}

[1] Suyanto 2000 Pendidikan di Indonesia Memasuki Milenium III Yogyakarta

[2] Andriani E, Indrawati and Alex H 2015 Remedi Miskonsepsi Beberapa Konsep Listrik Dinamis pada Siswa SMA Melalui Simulasi Phet Disertai LKS Jurnal Pendidikan Fisika 3 (4)362-369

[3] Kusumaningrum S and Djuksi 2016 Pengembangan Perangkat Pembelajaran Model PjB Untuk Meningkatkan Keterampilan Proses Sains dan Kreativitas Jurnal Inovasi Pendidikan IPA2 (2) p 241-245

[4] Abidin Y 2014 Desain Sistem Pembelajaran Dalam Konteks Kurikulum 201 (Bandung: PT Refika Aditama) p167

[5] Tiantong M and Siksen S 2013 The Online Project Based Learning Model Based on Student's Multiple Intelligence International Journal of Humanities and Social Science 3 (7) p 23-25

[6] Astuti R 2015 Meningkatkan Kreativitas Siswa Dalam Pengolahan Limbah Menjadi Trash Fashion Melalui PjBL Bioedukasi 8 (2) p 37-41

[7] Okudan G E and Sarah E R 2004 A Project-Based Approach to Entrepreneurial Leadership Education Journal Technovation XX p 1-16

[8] Taufina 2009 Authentic Assesment Dalam Pembelajaran Bahasa Indonesia di Kelas Rendah SD Pedagogi IX (1) p 113-120

[9] Sudewi 2008 Pendekatan Penilaian Berbasis Produk pada Praktikum Cipta Boga Sebagai Upaya Meningkatkan Kualitas Pembelajaran Jurnal Pendidikan Indonesia 5 (13) p 27-30

[10] Sugiyono 2010 Metode Penelitian Pendidikan: Pendekatan Kuantitatif, Kualitatif, dan R \& D Alfabeta Bandung p 86 
[11] Hwang W Y et al. 2007 Multiple Representation Skills and Creativity Effects on Mathematical Problem Solving Using a Multimedia Whiteboard System Educational Technology \& Society 10 (2) p 191-212

[12] Isa A and Jamil A 2012 How to Measure Students Creativity Journal of the Asian Conference on the Social Sciences Official Conference Proceedings p 21862303

[13] Asan A and Haliloglu Z 2005 Implementing Project Based Learning in Computer Classroom the Turkish Online Journal of Educational Technology 4(2) p 1-12

[14] Bas G 2011 Investigating the Effects of Project Based Learning on Students' Academic Achievement and Attitudes Towards English Lesson The Online Journal of New Horizons in Education 1 (4) p 75-80

[15] Chasanah A R U, Nur K, dan Harto N 2016 Efektivitas Model Project Based Learning terhadap Keterampilan Proses Sains dan Kemampuan Berpikir Kreatif Siswa pada Pokok Bahasan Kalor Kelas X SMAN 1 Wonosegoro Tahun Pelajaran 2014/2015 Jurnal Penelitian Pembelajaran Fisika 7 p 19-24

[16] Yance D R, Ermaniati R, and Fatni M 2013 Pengaruh Penerapan Model Project Based Learning (PBL) terhadap Hasil Belajar Fisika Siswa Kelas XI IPA SMA Negeri 1 Batipuh Kabupaten Tanah Datar Pillar of Physics Education 1 p 48-54

[17] Mahanal S 2009 Pengaruh Pembelajaran Project Based Learning (PjBL) pada Materi Ekosiste terhadap Sikap dan Hasil Belajar SiswaSMAN 2 Malang Jurnal tidak diterbitkanMalang

[18] Prabowo T S, Eko hariadi \& Nanik E 2015 Pembelajaran Rangkaian Listrik Berbasis Proyek Untuk Meningkatkan Akitivitas dan Prestasi Belajar Siswa TL SMK N2 Samarinda Jurnal Pendidikan Vokasi: Teori dan Praktek 3 (2) p 45-47

[19] Karlin, Wahono W, and Madlazim 2016 Pengembangan Perangkat Pembelajaran IP Model Proyek Untuk Melatihkan Berpikir Kreatif Siswa SMP Materi Gerak Benda Pendidikan Sains Pascasarjana Universitas Negeri Surabaya 5 (2) p 6270

[20] Wright T 2001 Karen in Motionthe Role of Physical Enactment in Developing an Understanding of Distance, Time, and Speed The Journal of Mathematical Behavior 20 (2) p 145-162

[21] Halil T 2008 Prospective of Science Teachers Conceptualizations about Project Based Learning. International Journal of Instruction 1(1) p 61-79

[22] Baker E, Trygg B and Otto P 2011 Project Based Learning Model, Relevant Learning for The $21^{\text {st }}$ Century Washington : Pacific Education Institute Available on www.pacificeducationinstitute.org .

[23] Boondee V, Kidrakarn P, and Sa-Ngiamvibool W 2011 A Learning and Teaching Model Using Project-based Learning (PBL) on the WEB to Promote Cooperative Learning European Journal of Social Science 21 (3) p 498-506 